\title{
Notes on Palaearctic scythridids, with descriptions of nine new species (Lepidoptera: Scythrididae)
}

\author{
Bengt $\AA$. Bengtsson
}

Bengtsson, B. Å. 2005: Notes on Palaearctic scythridids, with descriptions of nine new species (Lepidoptera: Scythrididae). — Entomol. Fennica 16: 207-220.

Nine new species of the microlepidopteran family Scythrididae from the Palaearctic region are described: Enolmis tunisiae sp.n., Scythris deprinsi sp. n., Scythris divergens sp. n., S. kaschmirica sp.n., S. linnavuorii sp.n., S. nepalensis sp. n., S. shafferi sp. n., S. tuzensis sp. n. and S. unguicella sp. n. Information on geographical distribution is given for some species recorded for the first time from various countries.

B. A. Bengtsson, Lokegatan 3, S-38693 Färjestaden, Sweden; E-mail: bab1@, spray.se

Received 24 January 2005, accepted 4 April 2005

\section{Introduction}

Since the comprehensive review of the west Palaearctic fauna of the family Scythrididae by Bengtsson (1997a), new discoveries have been made and several species new to science have been found throughout the Palaearctic region. While examining Palaearctic scythridids preserved in the Zoological Museum in Helsinki, Finland, six new species were discovered by Bengtsson (1997b). Moreover, some specimens collected by H. Hacker in Pakistan and India appeared to belong to species with partly Palaearctic distribution (Bengtsson 1997c); Scythris taygeticola was described from Greece (Scholz 1997), Scythris saarelai and Scythris gladiella from Spain (Nupponen \& Nupponen 1999, 2004), and from Tunisia Nupponen (2001) described two new species, viz. Scythris kefensis and $S$. spectatorella. In addition to valuable investigations of the biology of some Polish scythridids, Baran (2004) contributed one new species (Scythris buzkoi) from Ukraine. Furthermore, Courtois (1996) elucidated the problem with Scythris rouxella (Constant, 1865) and provided new data on the biology of some other French species.

Regarding the eastern and central parts of the Palaearctic region, more than twenty new species have been described principally by Finnish and Russian lepidopterists as a result of several entomological expeditions in the Ural Mountains, Altai Mountains, the Baikal area and other areas (Nupponen, et al. 2000, Nupponen \& Nupponen 2001, Nupponen 2003). Moreover, Sachkov (1995, 1998, 1999, 2000a, 2000b, 2002) primarily contributed faunistic and biological data of numerous scythridids from the Samara area, and with the co-author Sinev described several new species, including Scythris ustjuzhanini (Sachkov \& Sinev 2001). Sinev (2001) also described fourteen new species from eastern and central Russia, and clarified some nomenclatural issues. Earlier Sinev (1993) had described Scythris mikkolai and S. jalavai from the Altai area.

Some additions to the scythridid list have also been discovered from the southern parts of the 
Palaearctic region. Passerin d'Entrèves and Roggera (2003) described Apostibes dharhani from Pakistan, and one year later the same authors (Passerin d'Entrèves \& Roggera 2004) added the following species: Scythris tauromeniella (Italy), S. landryi (Tunisia), S. herati and S. nielseni (Afghanistan). Scythris ghaemii was discovered in Iran (Bengtsson \& Huemer 2003) and in the Alps Scythris arerai was found new to science (Huemer 2000).

Further observations and discoveries have recently been made, and an account of these is given below. The species are listed alphabetically in generic and specific order.

\section{Material and methods}

Scythridid specimens from the following collections and institutions were examined for this paper. Full-name private collections mentioned in the paper are not included in the list below. Acronyms follow the "Abbreviations for Insect and Spider Collections of the World" by Neal L. Evenhuis \& G. Alan Samuelson (http://hbs. bishopmuseum.org/codens/codens-inst.html).

BMNH (London, United Kingdom, The Natural History Museum [formerly British Museum (Natural History)])

BÅB (Bengt Å. Bengtsson, private collection)

FMNH (Helsinki, Finland, the Finnish Museum of Natural History)

MNHN (Paris, France, Muséum National d'Histoire Naturelle)

NMW (Wien, Austria, Naturhistorisches Museum Wien)

OLML (Linz, Austria, Oberösterreichisches Landesmuseum)

RMNH (Leiden, the Netherlands, Nationaal Natuurhistorische Museum ("Naturalis") [formerly Rijksmuseum van Natuurlijke Historie])

TLMF (Innsbruck, Austria, Tiroler Landesmuseum Ferdinandeum)

ZMAN (Amsterdam, the Netherlands, Universiteit van Amsterdam, Instituut voor Taxonomische Zoologie, Zoologisch Museum)

ZMHB (Berlin, Germany, Museum für Naturkunde der Humboldt-Universität)
ZMUC (Copenhagen, Denmark, Zoological Museum, the University of Copenhagen)

ZSMC (München [= Munich], Germany, Zoologische Staatssammlung)

The illustrations of imagines were made using Canon F1, Canon $50 \mathrm{~mm}$ macro lens with 2 and $60 \mathrm{~mm}$ extender. The genitalia pictures were produced with compound microscope Euromex EB and 5/0.10 achromat lens.

\section{List of species}

\section{Enolmis tunisiae sp. $\mathbf{n}$.}

Material examined. Holotype: $\widehat{\jmath}$, Tunesia, N. of Gafsa, 6.IV.1998, F. Iversen. Genitalia on slide BÅB 776X. In coll. ZMUC. Paratype: 2 ふふ, data as in holotype. In coll. ZMUC and in coll. BÅB. Genitalia of the last-mentioned male on slide BÅB 4418. Additional material: 1 ô, Tunisie, Bou Hedma, 1929, C. Dumont. In coll. MNHN?. Genitalia on slide Jä[ckh] 8715 (see "Note" below). 1 q, Tunisie, Tozeur, 1.IX.1929. In coll. MNHN?. Genitalia on slide Jä[ckh] 8716.

Diagnosis. Externally Enolmis tunisiae sp. n. is similar e.g. to E. acanthella (Godart, 1824) that occurs abundantly in the southwest of Europe, and to other closely-related species. Safe determination can only be attained using genitalia examination. In the male genitalia, the shape of the valvae is decisive, the right valva being stouter than in any other species of Enolmis. The female genitalia, however, are difficult to separate based on our present knowledge.

Imago (Fig. 1a-b): Wingspan 16-18 mm. Head intensively brown, face slightly paler. Scape brown with long, brown pecten. Flagellum brownish, length of cilia half that of flagellum diameter. Labial palps porrect or hardly ascending, short, brown, terminal joint with whitish ring at base. Neck tuft pale brownish. Tegulae and thorax brown with some pale scales. Forewing with whitish ground-colour and dark markings typical for the genus: at base a brownish grey blotch and outside this some small greyish spots; across midwing a fascia with straight inner margin and sometimes with minor interruption in middle; posteriorad of fascia an oval, blackish spot and above tornus one or two diffuse greyish spots; subapically an arch with greyish scales, originat- 
Fig.1. - a. Enolmis tunisiae sp. n., holotype. - b. Enolmis tunisiae sp. n. Copy of a photograph from coll. Jäckh: Paratype (female) with genitalia on slide Jä[ckh] 8716. - c. Scythris deprinsi sp. n., holotype. - d. Scythris divergens sp. n., paratype with genitalia on prep. BÅB $520 X$.

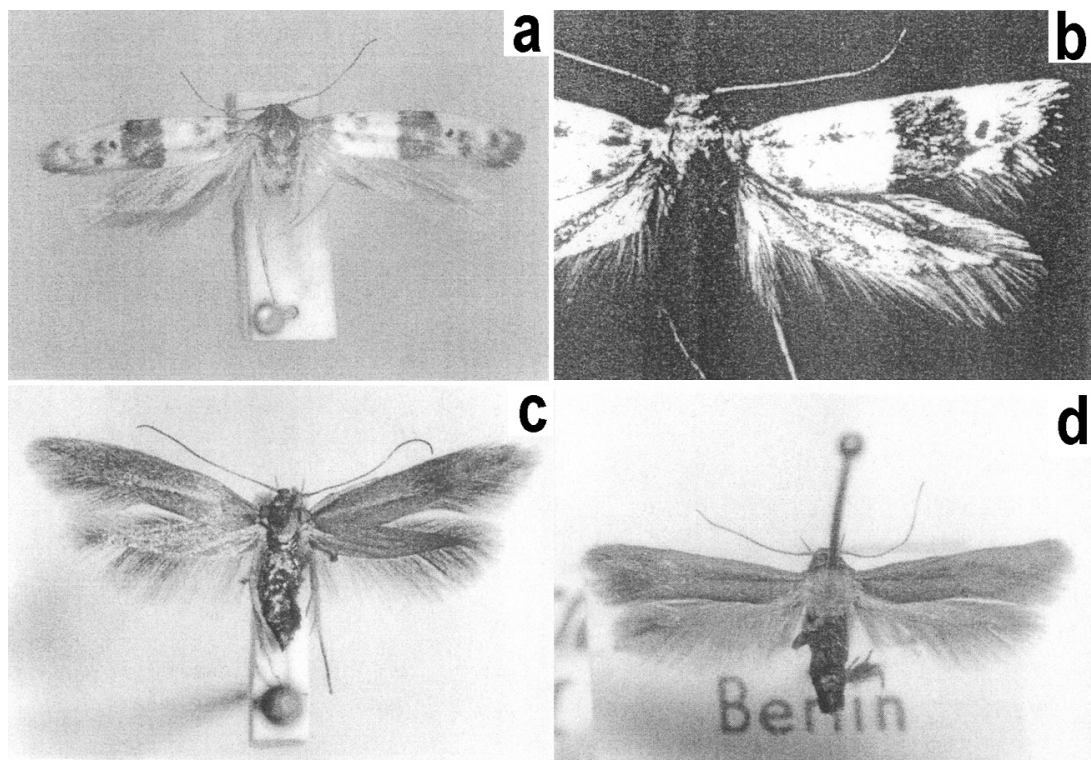

ing from tornus, not reaching costa. Fringe fuscous with paler base, around tornus dirty beige. Hindwing pale brownish grey with light brownish or dark, dirty beige fringe. Foreleg fuscous with beige inner surface. Midleg chequered in fuscous and pale beige, a broad ring at tibia most prominent. Hindleg pale beige or ivory. All legs with golden brown coxae. Abdomen dorsally brown beige or rusty yellow with paler hind margins on each segment, ventrally ivory; anal tuft ivory.

Male genitalia (Fig. 2a-b): Uncus subtrapezoid, rather slender, at posterior end shallowly incurved. Gnathos with short, basal loop and more or less hooked, distal arm. Left valva stout, constricted in middle, at end broad and rounded with additional long flap, and near the end of longitudinal ridge a dense brush with short, dark bristles. Right valva claviform, bent ventrally, distal part widened with more or less evident incurved distal margin. Aedeagus shorter than half length of left valva, slightly sigmoid, tapered, apex slightly hooked. Sternum 8 subtriangular with deep, medioanterior excavation, concave subapical sides and rounded tip with small, lateral projection. Tergum 8 a small, subtriangular, arched plate.

Female genitalia (Fig. 2d): Assuming the presented illustration actually belongs to E. tunisiae sp. n. (see "Note" below) the genitalia are diffi- cult to separate from those of E. userai (Agenjo, 1962). Henia with wide "head" and also wide in other parts, the whole of henia broader than in userai. Hind margin of sternum 7 reinforced by a sclerotized zone in shape of a flying bird seen from the front, medially with pair of digitate, subparallel processes.

Biology. Unknown. Imagines were found in early November and in early April.

Distribution. Only known from Tunisia.

Etymology. The species-name refers to Tunisia from where the type material originates.

Note. The two specimens under "Additional material" seem to be lost. When the late E. Jäckh was returning the specimens he had received for determination they apparently disappeared during transportation. There is a small possibility that they are deposited in the Smithsonian Institution, USA, where the rest of the Jäckh collection is preserved, but so far they have not been found there. Nevertheless, the male undoubtedly belongs to E. tunisiae sp. n., as the genitalia were photographed by Jäckh and are easily recognized (Fig. 2c). The female genitalia described in this paper probably belong to the new species as the external appearance (see Fig. 2d) does not match to the typical appearance of E. userai. Up to the present, E. userai is only recorded from Spain. The external appearance of the female is shown in Fig. 1b. 


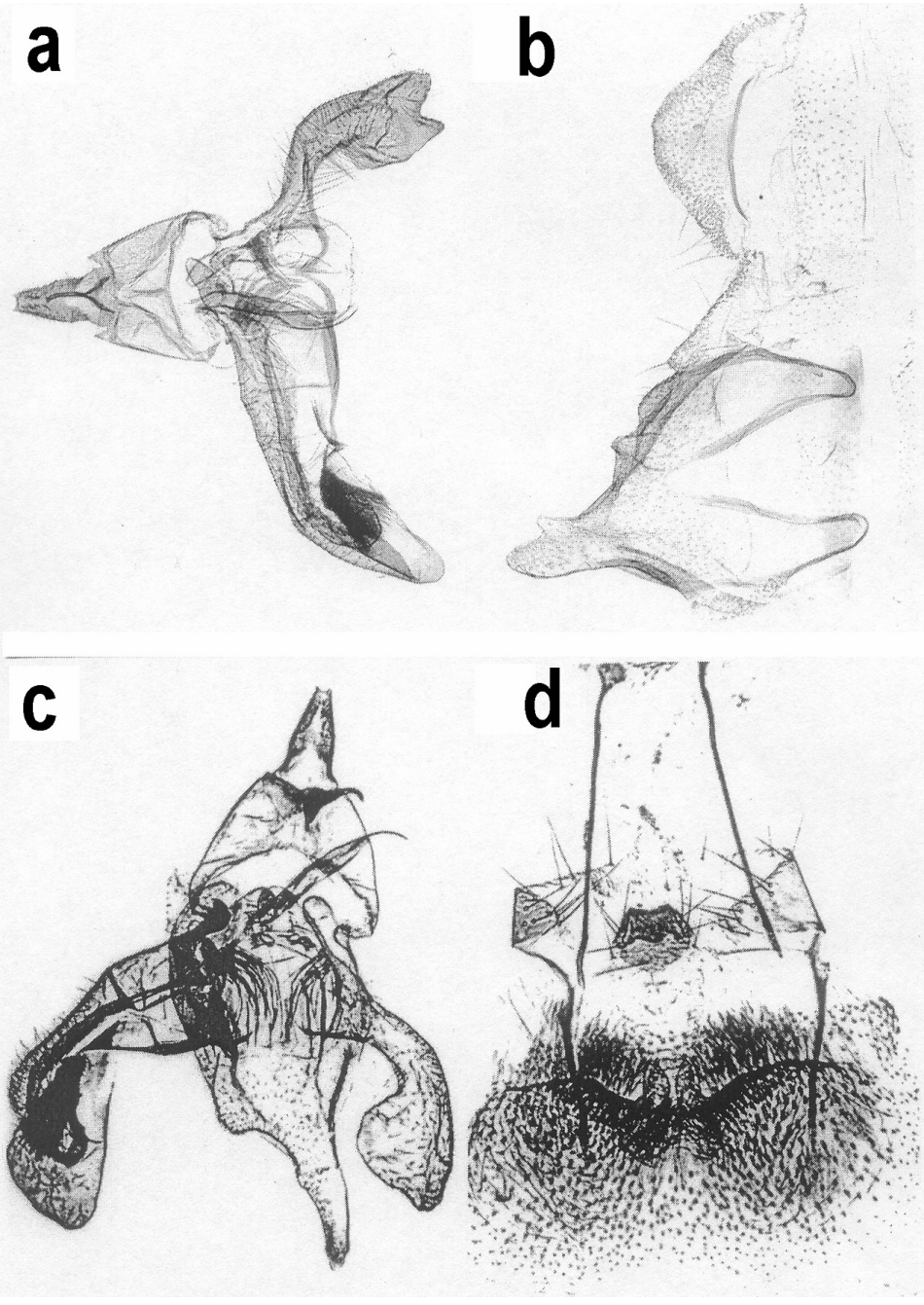

Fig. 2. - a. Male genitalia of Enolmis tunisiae sp. n., holotype. - b. Sternum 8 (bottom/left) and tergum 8 (top/right) of Enolmis tunisiae sp. n., holotype. - c. Male genitalia of Enolmis tunisiae sp. n. Tunisie, Bou Hedma, 1929, C. Dumont. Genitalia on slide Jä[ckh] 8715. Copy of photograph from coll. Jäckh. - d. Female genitalia of Enolmis tunisiae sp. $\mathrm{n}$. Tunisie, Tozeur, 1.IX.1929. Genitalia on slide Jä[ckh] 8716. Copy of photograph from coll. Jäckh.

\section{Scythris biacutella Bengtsson, 2002}

Material examined. $12 \AA \lambda, 7 q \circ$, Canary Islands, Spain, G[rand] C[anaria], Bco Arguineguin, 2 km S El Sao, 14.XI.1999, Varis [leg.]. In coll. FMNH. New to the Canary Islands [Spain]. Yemen.

Distribution. Canary Islands, Iran, Israel and

\section{Scythris complexa Sinev, 2001}

Material examined. $1 \hat{\jmath}$, China, Heilongjiand distr., Fenglin Nat. Res., 200-500 m a.s.1., 1219.VI.2000, Ikävalko [leg.]. In coll. FMNH. Distribution. China, Russia. New to China.

\section{Scythris curlettii Bengtsson, 1997}

Material examined. $4 \hat{\jmath} \widehat{\partial}, 1$, Elifaz n[ea]r
Timna, Israel, 19.IV.1986, Linnavuori [leg.]. In coll. FMNH.

Distribution. Egypt, Iran, Israel, 'Palestine', Tunisia. Previous reports on the distribution did not explicitly mention Israel.

\section{Scythris deprinsi sp. n.}

Material examined. Holotype: $\widehat{O}$, Bitlis, Turkey, B. van Oorschot; NEMRUT DAGI, 2,1002,450 m a.s.1., 30.VII-1.VIII.1988, St. 494. In coll. ZMAN. Paratypes: 1 $\widehat{\jmath}$, data as in holotype. Genitalia on slide BÅB 418X. In coll. ZMAN. - 1 ${ }^{\lambda}, 5 \mathrm{~km}$ S ERZURUM, Palandoken Daglari, 2,200-2,500 m a.s.1., St. 551; TURKYIE Erzurum, H. v. Oorschot, W. de Prins, F. Coenen, R. Koolbergen. In coll. BÅB. 

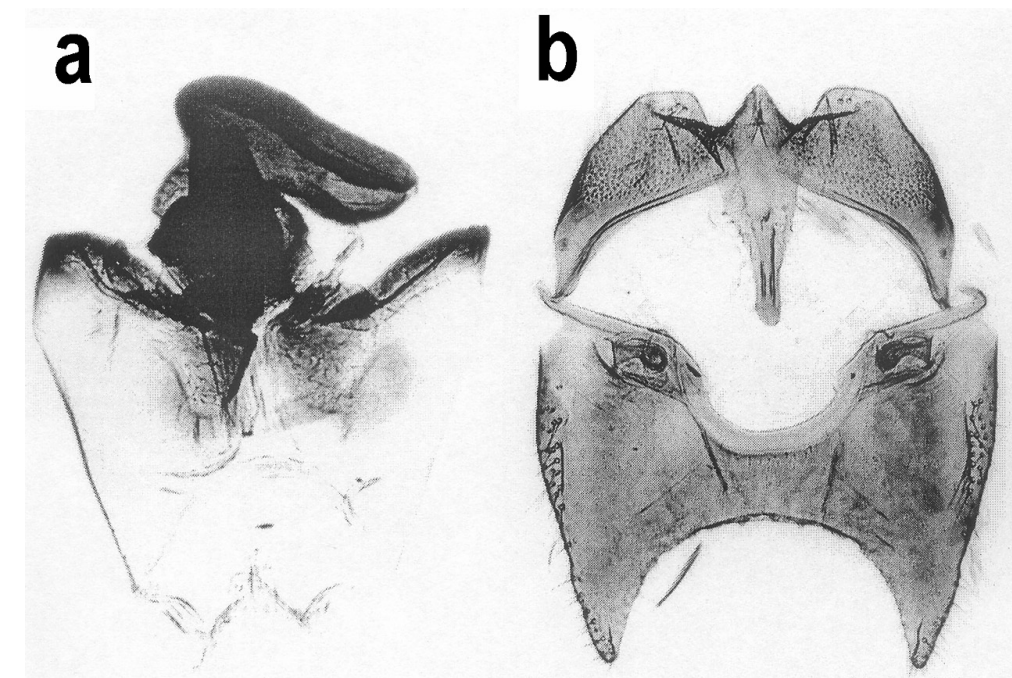

Fig. 3. - a. Male genitalia of Scythris deprinsi sp. n., paratype: Bitlis, Turkey, B. van Oorschot; NEMRUT DAGI, 2,100-2,450 m a.s.l., 30.VII-1.VIII.1988, St.494. Genitalia on slide BÅB 418X. -b. Tergum 8 (top) and sternum 8 (bottom) of Scythris deprinsisp. n., paratype. Data as in fig. 3a. - c. Male genitalia of Scythris divergens sp. n., holotype. - d. Sternum 8 (bottom/left) and tergum 8 (top/right) of Scythris divergens sp. n., holotype.
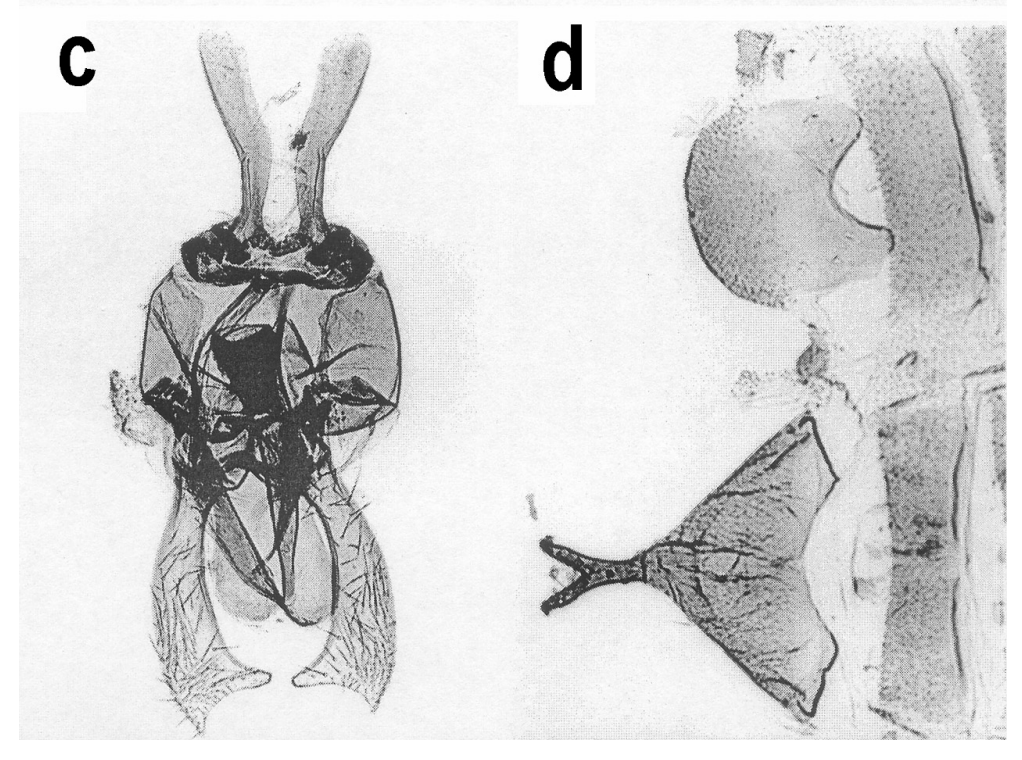

Diagnosis. Resembles superficially S. subaerariella (Stainton, 1867) and some other similar scythridid and cannot be safely determined without examination of the genitalia. The large, strongly sclerotized uncus with its distinctive shape is typical for the species and can already be discerned by gently removing the anal tuft.

Imago (Fig. 1c): Wingspan 11-12 mm. Head, antennae, labial palpi, tegulae, thorax and forewing essentially olive brown but flagellum with whitish scales beneath to beyond middle, basal joint of labial palpi cream, second joint with some cream scales. Forewing slightly glossy, with a cream streak in fold from base to tornal area, gradually disappearing, in apical area plenty of pale brown slender scales. Ventral side of thorax cream, glossy. Coxa and femur of all legs cream or very pale ochreous, tibiae ochreous or brown ochreous. Abdomen in male dark fuscous dorsally, ventrally dirty cream; anal tuft in lateral view with two short brushes.

Male genitalia (Figs. 3a-b): Several details in genitalia clumped and by conventional preparation superimposing. Uncus large, strongly sclerotized, shoe-shaped. Socii two closely situated setose lobes. Gnathos spatular, also strongly 
sclerotized. Valvae only setose edges of tegumen. Aedeagus very small, broad, with minute teeth along one side (not visible on Fig. 3a). Tegumen funnel-shaped, divergent posteriorly. Tergite 8 shaped as a flying falcon. Sternite 8 a broad plate with deep incurvation anteriorly and posteriorly.

Female genitalia: Unknown.

Bionomics. The species occurs in areas with volcanic soil at altitudes of 2,100-2,450 $\mathrm{m}$ a.s.1. with scarce bushes and grazed, low vegetation (De Prins, pers. comm.). Imagines were found in end of July-early August. Immature stages unknown.

Distribution. Turkey.

Etymology. This species is dedicated to W. De Prins who provided the type series.

\section{Scythris divergens sp. $\mathbf{n}$.}

Material examined. Holotype: $\hat{\jmath}$, Prov. Icel, Mut area, Turkey; 300-1,200 m a.s.1., 1.V.1993, O. Karsholt. Genitalia on slide BÅB 589X. In coll. ZMUC. Paratypes: 1 ڤ̂, [Turkey?] Eibes, 8.V.[year?], leg. (?)Staudinger. Genitalia on slide Jä 9579. In coll. ZMHB. - 1 ô, [Lebanon] Beyrouth, [leg.?] Staudinger. Genitalia on slide Jä 9582. In coll. ZMHB. - 1 ô, [Turkey] Zeitoon. (?)Staudinger leg. Genitalia on slide Jä 9641. In

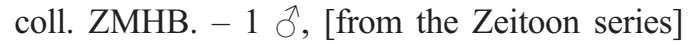
Genitalia on slide BÅB 520X. In coll. ZMHB. - 1 , Turkey: Prov. Nevsehir, Avanos-Ürgüp area, 4-6.V.1993, 1,000 m a.s.1., O. Karsholt. Genitalia on slide BÅB 590X. In coll. ZMUC. - 1 , Shar Devesy, Syria, 1893, Leech Nat.Coll. 61806. Genitalia on slide BÅB 651X. In coll. BMNH. -6 ふิ๋, 7 우, Anatolia, Manavgat, Turkey, 1.V.1996, K. Nupponen \& J. Junnilainen leg. Genitalia of one male on slide BÅB $732 \mathrm{X}$ and of one female on slide BÅB 733X. In coll. Nupponen, Junnilainen and BÅB.

Diagnosis. Can be separated from other dark scythridids only by dissection of the genitalia. In male the diverging uncus prongs and the incurved valva-tips are diagnostic features for $S$. divergens sp. n., in female the funnel-shaped antrum and the concave, postero-lateral sclerotization of the hind margin of segment 8 .

Imago (Fig. 1d): Wingspan 11-12 mm. Head, collar, labial palpi, antennae, tegulae, thorax and forewing dark brownish, fresh specimens with faint purplish gloss in forewing, old specimens
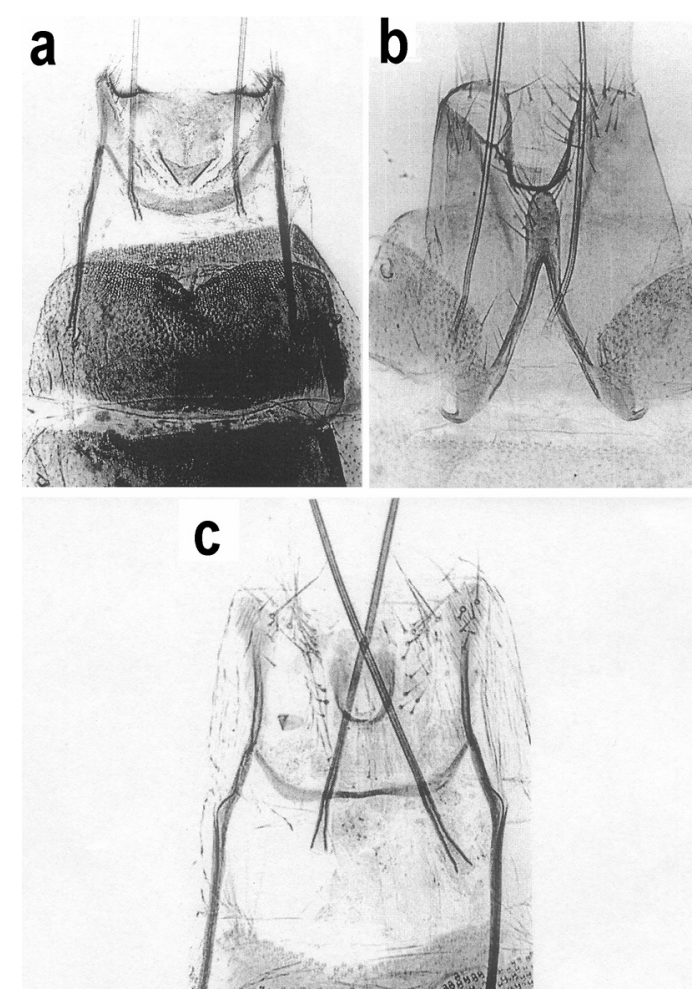

Fig. 4. - a. Female genitalia of Scythris divergens sp. n., paratype: Genitalia on slide BÅB 590X. - b. Female genitalia of Scythris kaschmirica sp. n., paratype: Genitalia on slide BÅB 645X. - c. Female genitalia of Scythris shafferi sp. n., paratype.

with olive hue and paler. Hindwings rich dark brown. Cilia blackish brown in both wings. Legs blackish brown. Coloration of abdomen in male as in forewing, anal tuft trifid; female abdomen with same colour but penultimate segments slightly paler ventrally.

Male genitalia (Fig. 3c-d): Uncus bifurcate, prongs diverging at normal preparation, tips about twice as broad as base. Gnathos long and slender, tapered, at tip curved. Valva bent, broadening terminally, tip concave. Aedeagus tapered, of about same length as valva. Sternum 8 subtriangular, posterior part with narrow bifurcate projection. Tergum 8 a broad plate, with smoothly rounded posterior edge.

Female genitalia (Fig. 4a): Sterigma subtriangular, lightly sclerotized, covering the whole of segment 8, a pair of posterolateral sclerotizations concave. Ostium with some minute 
Fig. 5. - a. Scythris kaschmirica sp. n., paratype: + , 31.VII. 1963, Afghan. centr., Bamian, Kasy \& Vartian. In coll. Kasy/NMW. - b. Scythris linnavuorii sp. n., holotype. - c. Scythris nepalensis sp. n., holotype. - d. Scythris tuzensis sp. n., holotype.

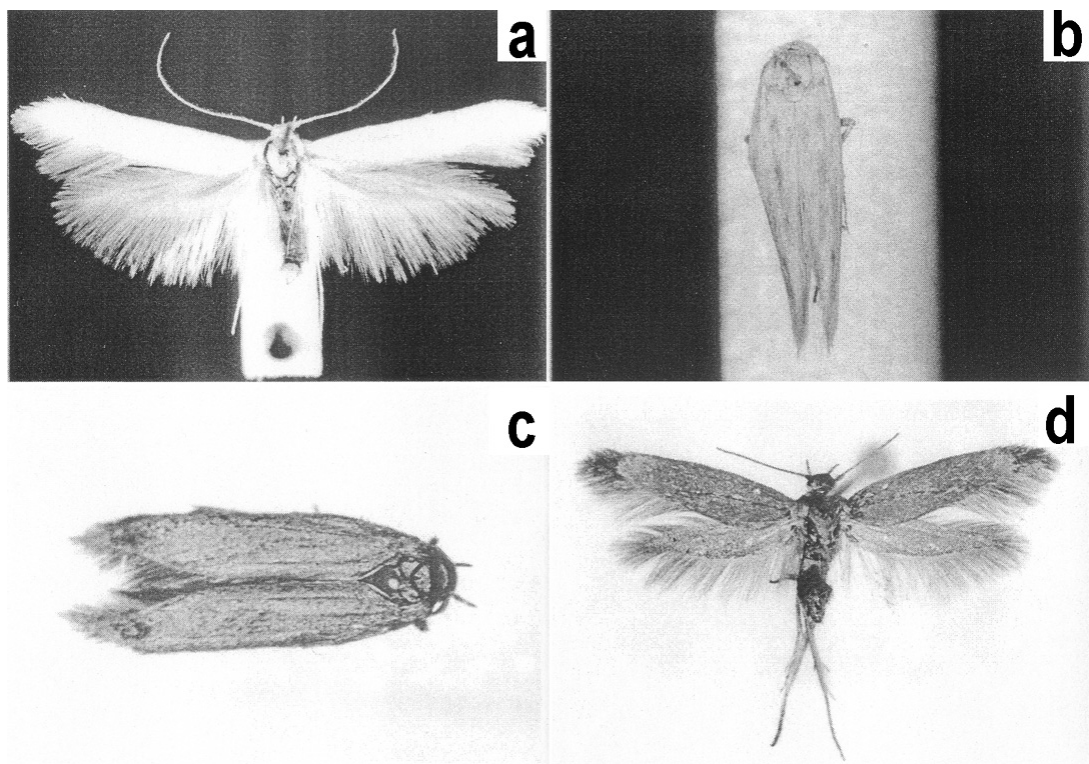

spines. Antrum funnel-shaped, distinctly outlined.

Biology. Unknown. Adults were found in May.

Distribution. Lebanon, Turkey.

Etymology. The species-name alludes to the shape of uncus and of the tip of the male sternum 8 (diverge $=$ diverto in Latin).

Note. This species belongs to the pascuella species-group (cf. Bengtsson 1997b) that comprises about 40 species.

\section{Scythris immaculatella (Chambers, 1875)}

Syn. Scythris kostjuki Sinev, 2001 [synonymized by d'Entrèves \& Roggera (2004)]

Material examined. 1 त, Heilongjiand distr., Fenglin Nat. Res., China, 200-500 m a.s.1., 411.VI.2000, Ikävalko [leg.]. In coll. FMNH.

Distribution. Nearctic: USA \& Canada (about 20 localities). Palaearctic: China, Russia. New to China.

\section{Scythris kaschmirica sp. $\mathbf{n}$.}

Material examined. Holotype: $\hat{\jmath}$, Kaschmir, 11-20.VII.1982, 10 km N Srinagar, M. u. E. Arenberger. Genitalia on slide BÅB 644X. In coll. Arenberger/NMW. Paratypes: $2+q$, data as in holotype. One specimen with genitalia on slide BÅB 645X. -1 \%, labelled as in holotype. -1 , 12-17.VII.1963, Afghanistan, $25 \mathrm{~km} \mathrm{~N} \mathrm{v.}$
Barikot, 1,800 m a.s.l., Nuristan, Kasy \& Vartian. - 1 q, 31.VII.1963, Afghan. centr., Bamian, Kasy \& Vartian. In coll. Kasy/NMW. - 1 , e.l. 27.VII.1963, Afghanistan, 25 km N v. Barikot, $1,800 \mathrm{~m}$ a.s.1., Nuristan, Kasy \& Vartian. Indigofera gerardiana. The above-mentioned paratypes in coll. Arenberger/NMW $-1 \delta, 2$ 우으, data as in holotype. In coll. BÅB.

Diagnosis. Externally well-marked specimens of $S$. kaschmirica may be confused with the Greek scythridid S. jaeckhi Bengtsson, 1989 but differ considerably in genitalia. Also superficially similar to $S$. paelopyga (Staudinger, 1880) from Turkey but the contrast between the whitish streak in the fold and the rest of the forewing is stronger.

Imago (Fig. 5a): Wingspan 11-14 mm. Head, antennae, tegulae and thorax olive fuscous. Labial palpi fuscous, basal third cream. Forewing olive grey, around fold and on midcosta very pale olive grey. Fringe olive fuscous. Hindwing and its fringe fuscous. Dorsal surface of hind leg tibia fuscous, rough-scaled, ventral surface whitish; tibia dark brown ventrally, dirty whitish dorsally. Abdomen of male tapered, dorsally ochreous brown, segment 1-2 dark grey; ventral side ochreous beige; anal tuft compressed and pointed posteriorly. Female abdomen broad, olive fuscous dorsally but segment $1-2$ greyish, cream ventrally. 

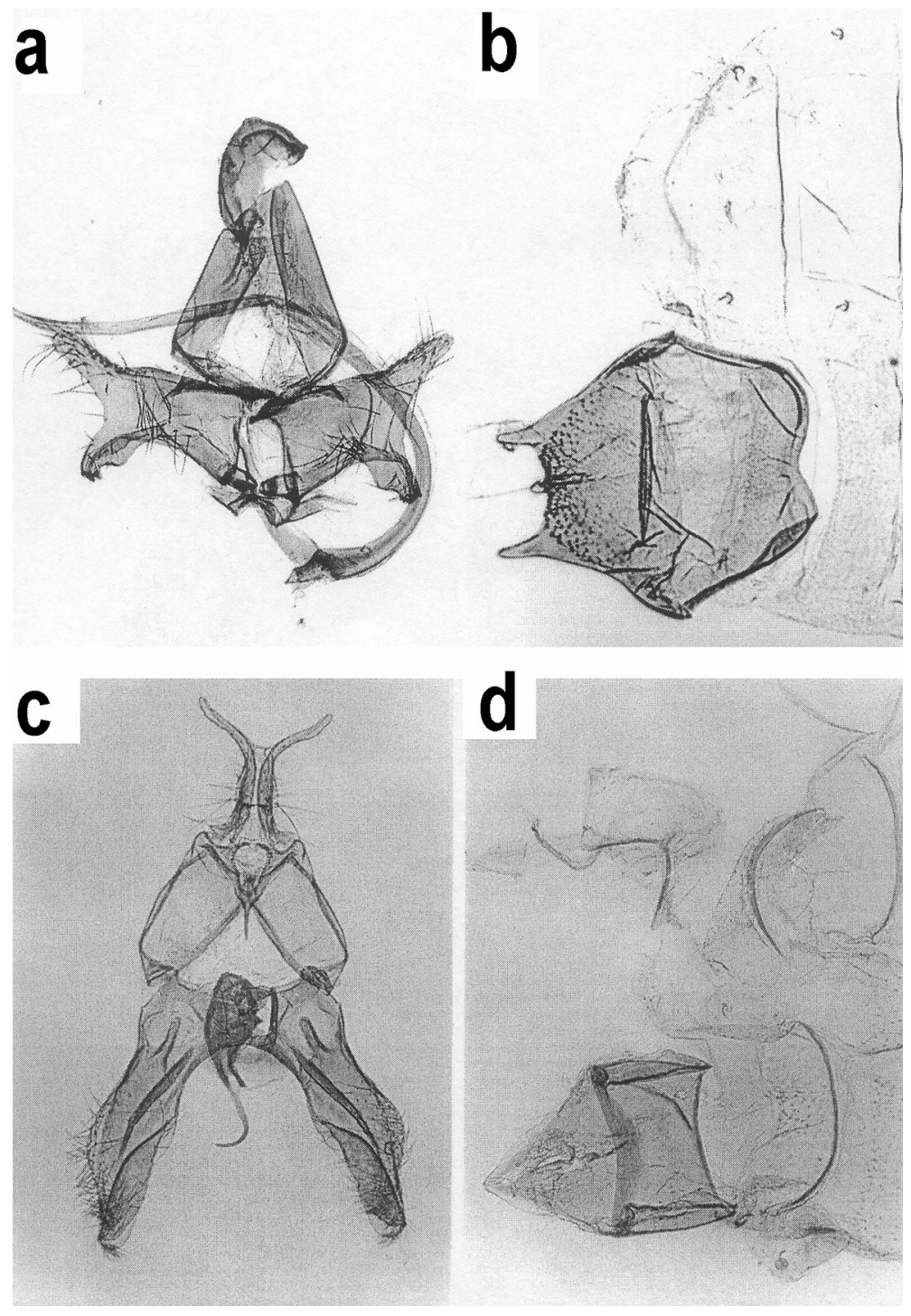

Fig. 6. - a. Male genitalia of Scythris kaschmirica sp. n., holotype. - b. Sternum 8 and tergum 8 of Scythris kaschmirica sp. n., holotype. -c. Male genitalia of Scythris linnavuorii sp. $\mathrm{n}$., holotype. - d. Sternum 8 (bottom/left) and tergum 8 (top/right) of Scythris linnavuorii sp. n., holotype.

Male genitalia (Fig. 6a-b): Uncus hoodshaped, large. Gnathos absent. Valvae straight, rather short, at tip widening in pair of digitate processes, diverging and widely separated from each other, the posterior process with long bristles, the anterior with short teeth at tip. Aedeagus very long, curved about $180^{\circ}$, almost evenly thick. Sternum 8 a hexagonal plate, medially with a transverse, sclerotized ridge, posteriorly with pair of horns. Tergum 8 a weakly membranous girdle.

Female genitalia (Fig. 4b): Ostium reniform, asymmetrically located to the left at the hind margin of segment 8. Anteroventral suture of seg- ment 8 bordered by long sclerotized rim. Apophyses anteriores very short, bent outwards or recurved.

Biology. Imagines were found in July. Host plant Indigofera gerardiana (Fabaceae), according to the label of one of the paratypes.

Distribution. Afghanistan, India (Kaschmir).

Etymology. The species name is referring to the region where the holotype was found.

Note. Based on the shape of uncus and lack of gnathos in the male genitalia, the very short apophyses anteriores, the medioventral structure of segment 8 and the asymmetrical position of 
Fig. 7. - a. Male genitalia of Scythris nepalensis sp. n., holotype. - b. Sternum 8 (bottom/left) and tergum 8 (top/right) of Scythris nepalensis sp. n., holotype.

-c. Male genitalia of

Scythris shafferi sp. n., holotype. - d. Sternum 8

(top/right) and tergum 8 (bottom/left) of Scythris shafferi sp. n., holotype.
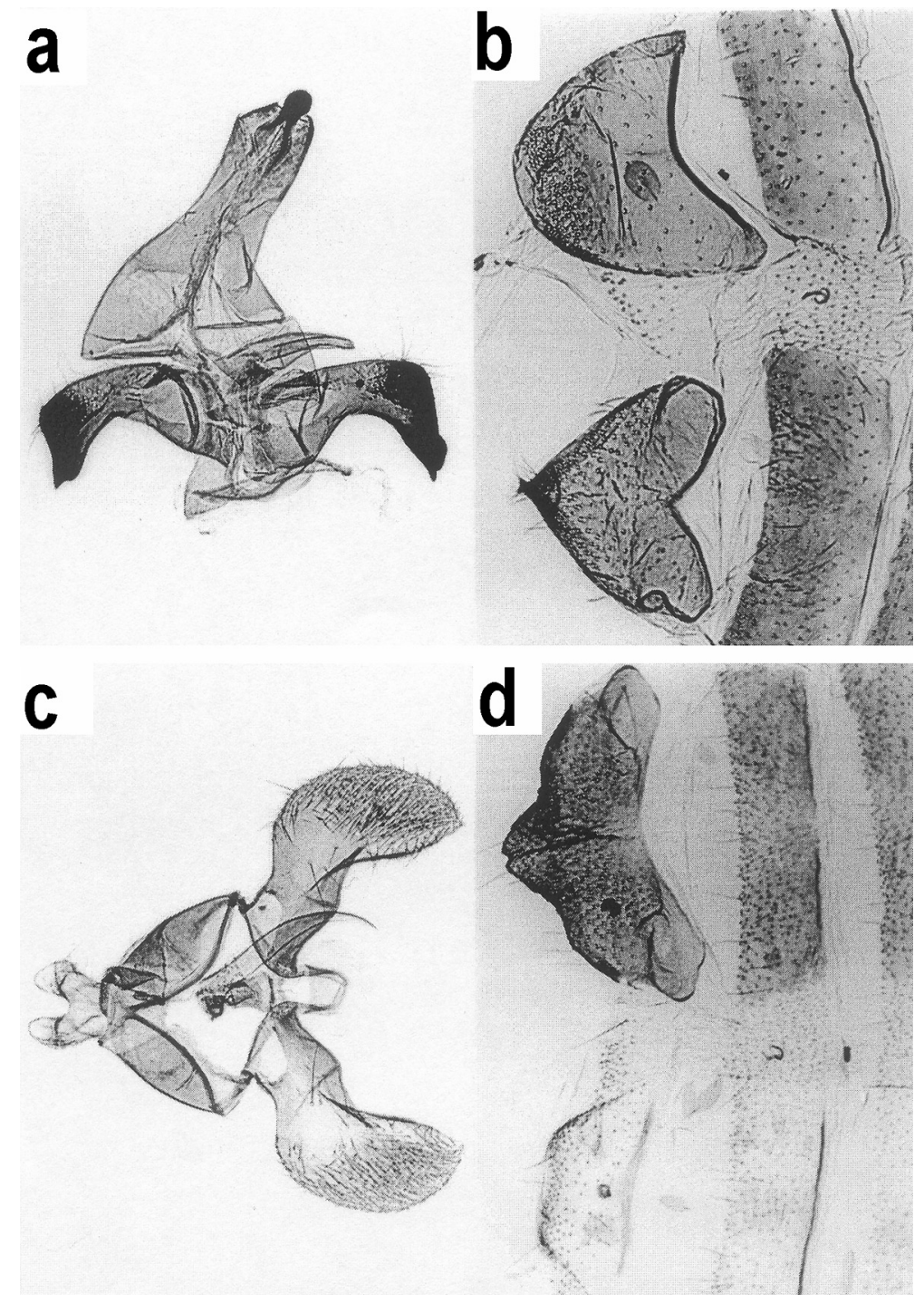

ostium in the female genitalia, Scythris kaschmirica belongs to the aerariella species-group.

\section{Scythris linnavuorii sp. $\mathbf{n}$.}

Material examined. Holotype: $\hat{\jmath}$, ISRAEL, S. Distr., Eilfaz nr Timna, 19.IV.1986, R. Linnavuori leg. Genitalia on slide BÅB 1046X. In coll. FMNH.

Diagnosis. Easy to confuse with a few species from the Arabian Peninsula but all of those are larger. Some Mediterranean species may be mixed up with the new species, e.g. Scythris canescens (Staudinger, 1880) and S. cupellella
Bengtsson, 1997 but both have a paler groundcolour. The genitalia of $S$. linnavuorii are distinct by the shape of uncus and aedeagus.

Imago (Fig. 5b): Wingspan $8 \mathrm{~mm}$. Whole moth ochreous beige, forewing with small, longitudinal, brownish dashes at $1 / 6$ and at $1 / 3$ in fold, and further suffusion of brownish scales in outer half, most concentrated in a dot above tornus. Flagellum with cilia longer than diameter of flagellum.

Male genitalia (Fig. 6c-d): Uncus large, anterior half narrow, with shorter and longer bristles and parallel-sided sclerotized bars that are diverg- 
ing strongly in distal half of uncus. Gnathos with almost closed, basal loop, whose inner side is granular; distal arm small, straight and tapered. Valvae symmetrical, digitatiform, distally with flap that is folded over the inner part of the distal half; near base on internal surface a slender, medial extension directed anteriorly. Aedeagus asymmetrical, sigmoid, with thick, complex basal half, with an extended proximal, narrow hook and a truncated, second extension. Sternum 8 pentagonal with transverse sclerotization in middle. Tergum 8 an arched plate, edged with a thin sclerotized rim in shape of a truncated wish-bone. Sternum 7 and tergum 6-7 with curved, thin borders.

Female genitalia: Unknown.

Biology. The holotype was found in April.

Distribution. Israel.

Etymology. The species is named in honour of the collector, the Finnish entomologist Rauno Linnavuori.

Note. Scythris linnavuorii is a member of the canescens species-group, defined by the following features in the male genitalia: a composite uncus, digitatiform valvae with longitudinal folds and flaps and sternum 8 reinforced by a transverse ridge (cf. Bengtsson 1997b).

\section{Scythris nepalensis sp. $\mathbf{n}$.}

Material examined. Holotype: $\widehat{\jmath}$, Mt. Pulchoki, Nepal, 2736' N 8525' E, 2,500 m a.s.1., malaise 10-12.V.1996, Exp. A. Albrecht, O. Biström, K. Mikkola \& A. Wikberg. Genitalia on slide BÅB 701X. In coll. FMNH. Paratypes: 2 $\hat{\jmath} \widehat{\jmath}$, labelled as in holotype. In coll. FMNH and in coll. BÅB.

Diagnosis. Cannot be separated from other plain, bronzy fuscous scythridids. Only dissection of genitalia may provide safe determination. The shape of gnathos and the valvae are distinct.

Imago (Fig. 5c): Wingspan 9-10 mm. Whole moth bronzy fuscous without markings in forewing. Labial palpi rather slender, ascending, reaching upper margin of eye. Abdomen dorsally dark fuscous, ventrally brownish silvery, becoming darker anteriorly. Anal tuft fuscous.

Male genitalia (Fig. 7a-b): Uncus vestigial. Gnathos knob-shaped, on pair of bent, slender and short arms. Tegumen extended posteriorly and comparatively narrow in distal half. Valvae slightly asymmetrical, but with about same doghead-shaped profile, constricted in middle. Aedeagus short, tapered, slightly bent. Vinculum a plate with U-shaped reinforcement. Sternum 8 subtriangular, anterior margin indented and distal tip with small bifurcate projection. Tergum 8 semicircular with concave anterior margin.

Female genitalia: Unknown.

Biology. Imagines were found in May in a malaise trap. Immature stages are unknown.

Distribution. Nepal (near Kathmandu).

Etymology. The species name is referring to where the holotype was found.

Note. Scythris nepalensis appears to be a member of the laminella species-group but the structure of gnathos is not quite typical for the group.

\section{Scythris nipholecta Meyrick, 1918}

Material examined. 1 $\lambda$, Tenerife, Puerto de la Cruz, Spain, 24.III.1995, Lepistö [leg.]. In coll. FMNH. New to the Canary Islands.

Distribution. Egypt, Spain (Canary Islands) and Sudan.

\section{Scythris parafuscoaenea Bengtsson, 1991}

Material examined. $1 \hat{\jmath}$, Portugal, Montesinho, $2.5 \mathrm{~km} \mathrm{~S}$ Moimenta, 1,017 m a.s.1., 31.III.2001, Nieukerken leg. In coll. Nieukerken/ RMNH. New to Portugal.

Distribution. France, Morocco, Portugal and Spain.

\section{Scythris shafferi sp. $\mathbf{n}$.}

Material examined. Holotype: $\delta$ : $\delta$ E Kasikoparan; 28.VIII.[18]82; Christoph Coll.; Walsingham Collection 1910-427; Subaerariella Stt.; HOLOTYPUS, Scythris shafferi Bengtsson ๙. Genitalia on slide BÅB 444X. In coll. BMNH. Paratype: 1 : 4 469; $\delta$ Kasi Kop; 7.VIII.[18]82 (underneath); Christoph Coll.; Walsingham Collection 1910-427; subaerariella; PARATYPUS Scythris shafferi Bengtsson $\bigcirc$. Genitalia on slide BÅB 443X. In coll. BMNH.

Diagnosis. Cannot be separated externally from other similar scythridids, especially since the type material is old and the forewing colours have faded or become browner. The male genitalia can be separated from the other species in the obscurella species-group by the wide valvae and 


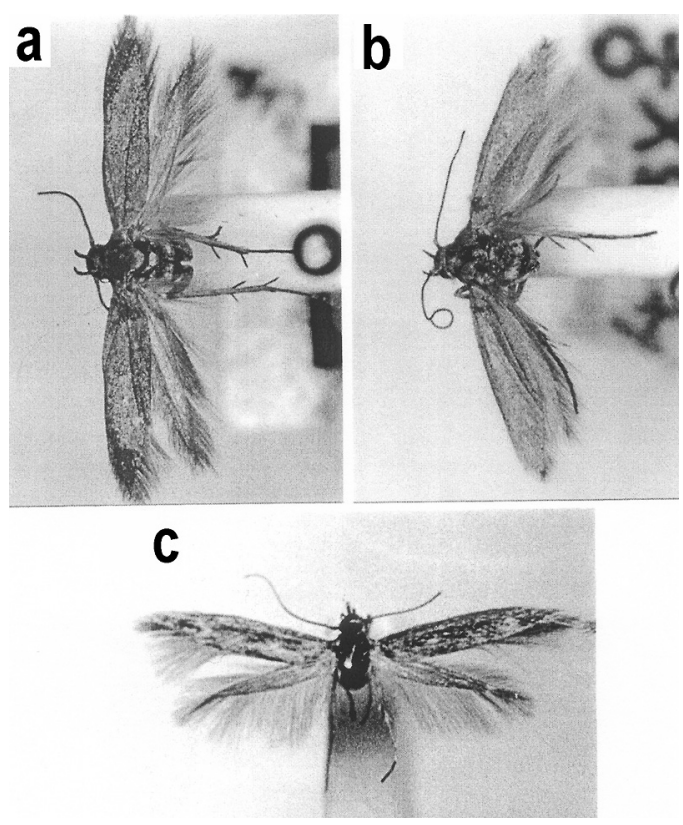

Fig. 8. - a. Scythris shafferi sp. n., holotype.

- b. Scythris shafferi sp. n., paratype. - c. Scythris unguicella sp. n., holotype.

the female genitalia have different sterigma compared to the close relatives in the group, particularly S. vernusella Jäckh, 1978 (see below).

Imago (Fig. 8a-b): Wingspan 12-13 mm. Head, antennae, tegulae, thorax and forewing fuscous. Labial palpi fuscous, on basal joint many whitish scales, on second joint some whitish scales. Hindwing pale greyish beige. Hind leg with bone-coloured tuft on upper surface, otherwise fuscous. Male abdomen fuscous, anal tuft rather compressed, covering the genitalia. Female abdomen fuscous dorsally, ultimate segment bone-coloured; ventral side fuscous, medially with bone-coloured scales, denser posteriorly, ultimate segment completely bone-coloured. Papillae anales protruding.

Male genitalia (Fig. 7c-d): Uncus U-shaped. Gnathos thorn-shaped with very broad base. Valvae basically scoop-shaped, broad and bent in middle. Aedeagus tapered, in terminal half evenly curved. Sternum 8 subtrapezoid, anteriorly concave, posteriorly with medial, shallowly cleft extension. Tergum 8 subtrapezoid, membranous.

Female genitalia (Fig. 4c): Sterigma Ushaped as in S. vernusella, but posterior part dif- fuse and not ending in sclerotized tips. Transverse bar between apophyses anteriores narrow and well defined. At each side of sterigma two conspicuous rows of short bristles. Ductus bursae evenly broad, indistinct.

Distribution. Turkey (Kasikoparan, i.e. today's Kagizman, situated in a NE-oriented valley of Asagi Dag).

Biology. Unknown. Imagines were found in August.

Etymology. This species is dedicated to Dr. Michael Shaffer at BMNH who provided these specimens from the museum.

Note. S. shafferi sp. $\mathrm{n}$. belongs to the obscurella species-group.

\section{Scythris subcassiterella Bengtsson, 1997}

Material examined. $1 \hat{\jmath}$, China, Heilongjiand distr., Fenglin Nat Res., 200-500 m a.s.1., Ikävalko [leg.]. In coll. FMNH. New to China.

Distribution. China and Russia (Primorskiy kray).

\section{Scythris subseliniella (Heinemann \& Wocke, 1876)}

Material examined. $1 \curvearrowright, 1$, Ohrid, Macedonia, 5.VII.1954, Hellén [leg.]. In coll. FMNH. New to Macedonia.

Distribution. Austria, Czech Republic, Germany, France, Hungary, Italy, Macedonia, Monaco, "Sovjet Union", Spain, Turkey, "Yugoslavia".

\section{Scythris tributella (Zeller, 1847)}

Material examined. 1 ô, Portugal, Montesinho, $2.5 \mathrm{~km} \mathrm{~S}$ Moimenta, $1,017 \mathrm{~m}$ a.s.1., 29.VII.2001, Nieukerken leg. In coll. Nieukerken/RMNH. New to Portugal.

Distribution. Albania, Austria, Belgium, Bulgaria, Corsica, Czech Republic, France, Georgia, Germany, Hungary, Italy, Libya, Macedonia, Montenegro, The Netherlands, Portugal, Romania, Sardinia, Sicily, Slovakia, Spain, Switzerland, "Yugoslavia".

\section{Scythris tuzensis sp. n.}

Material examined. Holotype: đิ, Turkey, 7.V.1996, Aksehir, 30 km SW Sultan Daglari, 1,200 m a.s.1., K. Nupponen. Genitalia on slide $\mathrm{BÅB}$ 708X. In coll. Junnilainen/FMNH. 


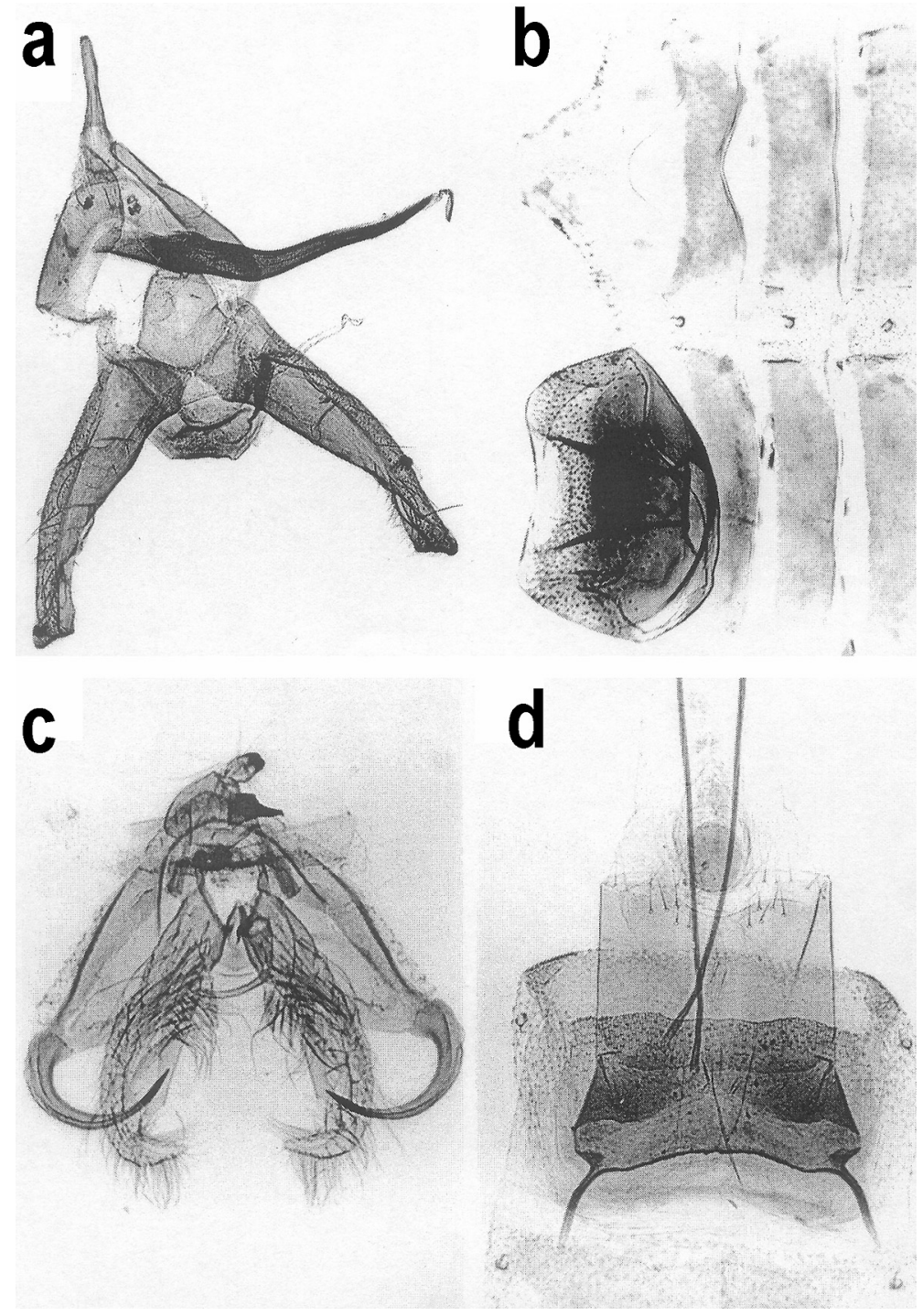

Fig. 9. - a. Male genitalia of Scythris tuzensis sp. n., holotype. - b. Sternum 8 (bottom/left) and tergum 8 (top/right) of Scythris tuzensis sp. n., holotype. - c. Male genitalia of Scythris unguicella sp. n., holotype. - d. Female genitalia of Scythris unguisella sp. n., paratype: genitalia on slide Jä[ckh] 7724 .
Paratypes: $4 \widehat{\jmath} \widehat{\jmath}$, Türkei, Prov. Ankara, 15 km SE Beypazari, $700 \mathrm{~m}$ a.s.1., 12.IX.1983, leg. Gg. Derra. Genitalia on slide Derra 3847. Three specimens in coll. Derra and one in coll. BÅB. $-1 \hat{\jmath}$, Turkey, 27.VII.1997, Aksehir, 25 km SW Sultan Daglari, 1,500 m a.s.1., K. Nupponen \& J. Junnilainen. Genitalia on needle in plastic tube. In coll. BÅB. - 1 ô, Turkey, 30.VIII.1997, Aksehir, 30 km SW Sultan Daglari, 1,500 m a.s.1., K. Nupponen \& J. Junnilainen. Genitalia on slide Nupp. 9/25.04.98. In coll. Nupponen - 1 đे, Turkey, 27.VII.1997, Aksehir, 30 km SW Sultan Daglari, 1,500 m a.s.1., K. Nupponen. In coll.
Nupponen. - $1 \hat{\jmath}$, Turkey, Antalya, $40 \mathrm{~km} \mathrm{~N}$ Analya, $5 \mathrm{~km} \mathrm{~S}$ Gündogmus, 1,100 m a.s.1., 14.VII.1987, Fibiger [leg.]. In coll. ZMUC. Additional material: $1 \hat{\delta}$, [Turkey] Asia Minor, Tuz Gölli, Nordufer, 20.VII.1970, leg. Friedel. Genitalia on slide Jä 6539. In coll. Burmann. - 1 ふ,, [Turkey] Asia Minor, Erigli Ivriz, 19.VII.1970, leg. Friedel. Genitalia on slide Jä 7238. In coll. Burmann/TLMF. - 1 ऽ̄, [Turkey] Kurdistan, Wan Umgeb., 2,000 $\mathrm{m}$ a.s.1., 22-27.VIII.1935, leg. Osthelder. Genitalia on slide Jä 8608. In coll. Osthelder/ZSMC.

Diagnosis. Similar to several other scythri- 
dids, in particular pale specimens of $S$. tributella (Z11.), S. deprinsi sp.n. and S. gravatella (Z11.) but male genitalia decisive by long and slender uncus, rudimentary gnathos, very long aedeagus and large juxta plate.

Imago (Fig. 5d): Wingspan 9-10 mm. Head, tegulae, thorax and forewing pale fuscous; forewing with plenty of whitish scales in fold to tornus and in apical area along termen (in a broad streak); also scattered whitish scales in the rest of forewing. Labial palpi whitish on first joint and also whitish around eye; palpi otherwise pale fuscous. Antennae and hindwing fuscous. Fringes in forewing fuscous, contrasting to the pale apical part of forewing. Fore- and midleg pale fuscous, hindleg whitish. Abdomen fuscous dorsally, ivory ventrally; anal tuft yellowish dorsally and whitish ventrally.

Male genitalia (Fig. 9a-b): Uncus elongate, narrow, articulated to tegumen. Gnathos vestigial. Aedeagus very long, straight or slightly curved and slender. Juxta a large, bell-shaped plate. Valvae rather narrow, slightly tapering and bent, apex obliquely truncate. Sternum 8 a broad, strongly sclerotized, subhexagonal plate with rounded corners, concave posteriorly. Tergum 8 subtrapezoid, weakly sclerotized, deeply concave anteriorly.

Female genitalia: Unknown.

Biology. The adults were found in July-September.

Distribution. Turkey.

Etymology. The species-name refers to the finding place (Tuz Gölli = Tuz Gölu) of one of the paratypes.

Note. The assignment of Scythris tuzensis sp. n. to an explicit species-group can not be done before the female is found.

\section{Scythris unguisella sp. $\mathbf{n}$.}

Material examined. Holotype: $\hat{\jmath}$, [Turkey] Anatolia, Sille-Konya, 10.VI.1966, [leg.] Klimesch. Genitalia on slide Jä 7720. In coll. Klimesch/ZSMC. Paratypes: 1 , data as in holotype. Genitalia on slide Jä 7724. In coll. Klimesch/ZSMC. - 1 , Asia Minor, Sille b. Konya, 10.VI.1966. In coll. BÅB.

Diagnosis. May be recognised by the mottled forewing with diffuse markings. Male genitalia with huge, claw-shaped apical processes on sternum 8. Segment 8 in female angular, with short apophyses anteriores and without a sclerotized, curved ridge connecting the apophyses; sterigma round.

Imago (Fig. 8c): Wingspan 9.0-10.5 mm. Head greyish brown, with whitish scales around eye, especially above eye. Antennae two third of forewing length, fuscous, scape whitish ventrally. Labial palpi ascending, curved, reaching height of antennal base, fuscous in terminal joint and proximal half of second joint, the rest of palpi pale beige. Collar pale brown, neck tuft ivory. Tegulae pale brown with many ivory scales at tip. Thorax pale fuscous. Forewing fuscous with the following diffuse whitish markings: at dorsum near base, in fold at $2 / 5$ and $3 / 5$, and from tornus and further in whole apical area, where a dark brown spot stands in the pale area. Hindwing pale fuscous, darker distally. Fringe in both wings fuscous. Legs dark beige, last two tarsal joints darker, and bristles on tibia bone coloured. Abdomen coloration in male unknown; in female fuscous dorsally, whitish ventrally. Posterior scales in segment 7 ochreous.

Male genitalia (Fig. 9c): Uncus ellipsoid with sclerotized and indented tip. Gnathos broad at base, terminal part beak-shaped. Valvae membranous, curved, almost hook-like, with three flaps: one on inner border at $1 / 3$, one large on inner border in mid valva, and a small one in subapical area. Tergum 8 membranous. Sternum 8 two big subtriangular plates, very peculiar in having a posterior, giant hook on each plate reminding of a claw of a raptorial bird.

Female genitalia (Fig. 9d): Sterigma ellipsoid. Segment 8 rectangular when genitalia are pressed at preparation. Apophyses anteriores short and slightly bent.

Bionomics. Imagines were collected in June. Holotype and first paratype caught on Lycium sp., which might be the host plant.

Distribution. Turkey.

Etymology. The name unguisella refers to the strange terminal claw-shaped structure of sternum 8 in male (claw $=$ unguis in Latin).

Note. The strange genitalia of both male and female suggest that Scythris unguicella sp. $\mathrm{n}$. forms a species-group of its own. 
Acknowledgements. I am deeply indebted to Dr. Lauri Kaila, Mr. Kari Nupponen, and Mr. Jari Junnilainen for letting me examine the material preserved at the Zoological Museum, Helsinki, Finland, and in private collections. I also thank Mr. Ole Karsholt, Mr. W. de Prins and Dr. Erik J. van Nieukerken for providing important material. Finally, I express my gratitude to two anonymous referees who contributed with valuable improvements on the manuscript.

\section{References}

Baran, T. 2004: Scythris buzkoi sp.n., a new species of Scythrididae from Europe (Gelechioidea). - Nota Lepid. 26 (3/4): 89-98.

Bengtsson, B. Å. 1997a: Scythrididae. — In: Huemer, P., Karsholt, O. \& Lyneborg, L. (eds.): Microlepidoptera of Europe 2: 1-301.

Bengtsson, B. A.. 1997b: Notes on interesting scythridids in the Zoological Museum, Helsinki, Finland (Lepidoptera, Scythrididae). — Entomol. Fennica 8: 89102.

Bengtsson, B. Å. 1997c: Scythridids found by H. Hacker in Pakistan 1988 and India 1992. — Esperiana 4[1996]: 467-481.

Bengtsson, B. A. \& Huemer, P. 2003: Eine neue Art der Familie Scythrididae aus dem Iran (Lepidoptera, Scythrididae). — Carinthia II 193/113: 573-578.

Courtois, J.-M. 1996: Troisième contribution à la conaissance des Lépidoptères Scythrididae de France. Qu'en est-il de Scythris rouxella Constant, 1865, espèce problematique? — Alexanor 19 (6): 367-372. [In French.]

Huemer, P. 2000: Endemismus am Beispiel der Scythris fallacella (Schläger, 1847) - Gruppe (Lepidoptera: Scythrididae). - Entomol. Zeitschr. Stuttgart 110(8): 244-249.

Nupponen, K. 2001: Records of scythridids from Tunisia, with description of two new species (Lepidoptera: Scythrididae). - Entomol. Fennica 12: 53-58.

Nupponen, K. 2003: Contribution to the scythridid fauna of southern Buryatia, with description of seven new species (Lepidoptera: Scythrididae). — Entomol. Fennica 14: 25-45.

Nupponen, K. \& T., 1999: Scythris saarelai sp. n. from southern Spain and further records of Scythris mariannae Bengtsson, 1991 with a new synonymy (Lepidoptera: Scythrididae). — Entomol. Fennica 10: 161-166.

Nupponen, K. \& Nupponen, T. 2001: Notes on the scythridid fauna of the Altai Mountains, with description of four new species (Lepidoptera: Scythrididae). — Entomol. Fennica 12: 81-93.

Nupponen, K. \& Nupponen, T. 2004: Notes on Scythri- didae recorded in southern Spain during 2003, with description of one new species (Lepidoptera: Scythrididae). - SHILAP Revta. lepid. 32 (125): 3137.

Nupponen, K., Bengtsson, B. Å., Kaitila, J.-P., Nupponen, T., Junnilainen, J. \& Olschwang, V. 2000: The scythridid fauna of the southern Ural Mountains, with description of fourteen new species (Lepidoptera: Scythrididae). - Entomol. Fennica 11: 5-34.

Passerin d'Entrèves, P. \& Roggera, A. 2003: Description of two new species of Apostibes Walsingham, 1907 with some synonymic and phylogenetic accounts of the genus (Lepidoptera, Scythrididae). - Ital. J. Zool. 70: 347-352.

Passerin d'Entrèves, P. \& Roggera, A. 2004: Four new species, a new synonymy and some new records of Scythris Hübner, [1825] (Gelechioidea: Scythrididae). — Nota Lepid. 26 (3/4): 153-164.

Sachkov, S. A. 1995: New for Europe species of Microlepidoptera (Lepidoptera: Scythrididae, Elachistidae) from Samara Region. - Actias 2(1-2): 77-78.

Sachkov, S. A. 1998: K' faune mrachnykh molē̄ (Lepidoptera, Scythrididae) Samarskoj oblasti. — Samarskij gosudarstvennyj universitet. Izdatelstvo "Samarskoj universitet" 1998: 48-50. [In Russian.]

Sachkov, S. A. 1999: The Distribution of Scythridid Moths (Lepidoptera, Scythrididae) in the European Part of Russia. - International conference: Biodiversity of Terrestrial and Soil Invertebrates in the North. (Abstract): 176-178.

Sachkov, S. A. 2000a: Novye vidy mrachnykh moleī (Lepidoptera, Scythrididae) iz Srednego Povolzh'ja. —Zoologichesk̄11 zhurnal 79(12): 1479-1484.

Sachkov, S. A. 2000b: K' faune mrachnykh moleī (Lepidoptera, Scythrididae) Ul'ianovskoi oblasti. Nasekomye i paukoobraznye Ul'ianovskoi oblasti 9: 103-111. [In Russian.]

Sachkov, S. A. 2002: A new and a little-known species of Scythris Hübner, 1825 (Lepidoptera: Scythrididae) from Kazakhstan and the Middle Volga, and three species of Scythris newly synonymised. - Entomologist's Gazette 53: 259-264.

Sachkov, S. A. \& Sinev, S. Yu. 2001: A new species of the genus Scythris Hbn. (Lepidoptera, Scythrididae) from Transbaikalia. - Proceedings of the Zoological Institute, St. Petersburg 291: 27-30.

Scholz, A. 1997: Scythris taygeticola sp. n., eine neue Scythris-Art aus Griechenland (Lepidoptera: Scythrididae). — NachrBl. Bayer. Ent. 46 (1/2): 35-38.

Sinev, S. Yu. 1993: New and little-known species of the genus Scythris (Lepidoptera, Scythrididae) from Altai. — Vestn. Zool. 2: 53-57.

Sinev, S. Yu. 2001: New and little-known species of the genus Scythris Hbn. (Lepidoptera, Scythrididae) from the Asiatic part of Russia. - Proceedings of the Zoological Institute, St. Petersburg 291: 3-26. 